\title{
thebmi
}

Editorials Christmas 2009: Professional matters

\section{Where have all the hospital flowers gone?}

BMJ 2009; 339 doi: http://dx.doi.org/10.1136/bmj.b5406 (Published 17 December 2009) Cite this as: BMJ 2009;339:b5406

\author{
Simon Cohn, medical anthropologist \\ ${ }^{1}$ General Practice and Primary Care Research Unit, Institute of Public Health, Cambridge University, Cambridge CB2 \\ OSR
}

simon.cohn@medschl.cam.ac.uk

They have fallen victim to new definitions of care

Christmas is a time for giving, so it is timely to consider the reasoning behind the extensive and growing ban on giving flowers to patients in hospital. The article by Giskin Day and Naiome Carter describes how both individual wards and entire hospitals are using their discretion to prohibit flowers on the ward, in the absence of any official ruling from the Department of Health.1 It is undoubtedly causing consternation for patients and visitors alike.

The reasons for such prohibitions are varied, something that should immediately make us curious. As Day and Carter point out, some argue that it is about reducing the risk of injury from broken glass, or avoiding the depletion of oxygen in the air from decomposing material, or even avoiding water spillage over modern electronic equipment. In addition, some staff cite the inconvenience of changing water regularly and the problems of disposing of dead flowers. Unsurprisingly, in the context of invigorated concern around hospital cleanliness, the most common explanation relates to hygiene-that either the flowers themselves, or the water in their vases, carry a risk of infection.

However, none of these explanations has a secure evidence base. Although it is not surprising to learn that flower water can contain bacteria,2 3 rigorous studies have emphatically concluded that bedside flowers pose no particular threat to health.4 But what is of interest is just how widespread the bans are, despite the evidence. Post hoc rationalisations of practices seem, by definition, logical and sensibleusing partial bits of knowledge to mask, often from the protagonists themselves, the fact that an a priori decision was based not on facts but on values. For this reason, even compromises such as those Day and Carter present-for example, specifying the best kind of flowers or designating a shared common place-are no less perplexing, because they indirectly reinforce the idea that flowers are essentially inconvenient or pose some kind of hazard.

Of course, this may not seem particularly important for hospital staff in the context of their extensive responsibilities, and we should be sympathetic to this. But the matter is important to patients and their visitors. The point about giving is that it reinforces meaningful relationships of love and friendship.5 And hospital gifts are perhaps even more nuanced than this. Firstly, the gifts are traditionally ephemeral in 
nature-whether flowers, fruit, or chocolate, there is something reassuring about them lasting a finite period, echoing the hope that soon the patient will recover and head home. Secondly, although giving flowers can be a sign of private intimacy, in a hospital setting the flowers also publically demonstrate social ties beyond visiting hours. A patient looking at a bouquet doesn't just see the flowers but the person who gave them. And a nurse or doctor is often part of this-remarking on the gifts in small talk, and consequently becoming entangled in a comforting form of interaction.

The apparent intransigence of hospital staff in the face of evidence suggests there might be more to this ban than merely the flowers themselves. In anthropological terms, hygiene is not defined by things being essentially "dirty," but by things being perceived to be in the wrong place6-for example, soil is fine in the garden but dirty when on the carpet. So how is it that although flowers were once fine at a hospital bedside, they are suddenly in the wrong place and therefore unclean? Perhaps it is because flowers can mark out a small personalised space, domestic and non-clinical, where a different mode of relating can take place, and it is this that is really out of place on a modern ward.

Underlying all the explicit arguments, the decision to ban flowers seems to reflect a much broader shift towards a model of care that has little time or place for more messy and nebulous elements.7 The development is not the articulation of rational science but increased rationalisation in the sociological sense, which equates with technical efficiency coupled with greater bureaucracy and accountability. The practice of healthcare delivery - with more prescriptive guidelines and targets, greater demands on time, and more explicit professional roles-means that there is simply not room for the more vague, apparently superfluous, practices on a well functioning ward. The flowers have been elbowed out.

And so, in the context of health priorities, such an apparently inconsequential policy reflects a more general shift in current definitions of care. At this time of year, despite all the calls of commercialisation and trivialisation, in truth most of us still value ritualised contact with loved ones and the demonstration of relationships through giving and receiving. Perhaps, then, now is a good time to think about a broader version of care that increasingly needs to be protected on the ward and within the everyday practices of a hospital. Such a version of care would be thought of not as an outcome that can be delivered but as a relationship that can be exchanged.

\section{Notes}

Cite this as: BMJ 2009;339:b5406

\section{Footnotes}

\section{- Feature, doi:10.1136/bmj.b5257}

- Competing interests: None declared.

- Provenance and peer review: Commissioned; not externally peer reviewed.

\section{References}

1. Day G, Carter N. Wards of the roses. BMJ2009;339:b5257.

2. Kates S, McGinley K, Larson E, Leyden J. Indigenous multiresistant bacteria from flowers in hospital and nonhospital environments. Am J Infect Control1991;19:3156-61. 
3. Taplin D, Mertz P. Flower vases in hospitals as reservoirs of pathogens. Lancet1973;302:1279-81.

4. Gould D, Chudleigh J, Gammon J, Ben Salem R. The evidence base and infection risks from flowers in the clinical setting. Br J Infect Control 2005;6:18-20.

5. Mauss M. The gift: forms and functions of exchange in archaic societies. London: Routledge, 1990.

6. Douglas M. Ritual uncleanliness. Purity and danger. London: Routledge, 1966.

7. Mol A. The logic of care: health and the problem of patient choice. London: Routledge, 2008. 